WAR AND THE CREATIVE ARTS

AN ANTHOLOGY 


\section{WAR \\ and the \\ CREATIVE ARTS}

AN ANTHOLOGY

Edited by

\section{JOHN FERGUSON}

Dean and Director of Studies

Faculty of Arts

The Open University

Published by

MACMILLAN

in association with

Palgrave Macmillan 


\section{ISBN 978-0-333-14114-4 ISBN 978-1-349-15490-6 (eBook) \\ DOI 10.1007/978-1-349-15490-6}

Selection and editorial matter copyright (C) The Open University 1972

Reprint of the original edition 1972

All rights reserved. No part of this publication may be reproduced or transmitted, in any form or by any means, without permission from the publisher

First published 1972 by

THE MACMILLAN PRESS LTD

London and Basingstoke

Associated companies in New York Toronto

Dublin Melbourne Johannesburg and Madras

SBN 333141121 (hard cover)

333141148 (paper cover)

The paperback edition of this book is sold subject to the condition that it shall not, by way of trade or otherwise, be lent, re-sold, hired out, or otherwise circulated without the publisher's prior consent in any form of binding or cover other than that in which it is published and without a similar condition including this condition being imposed on the subsequent purchaser. 


\section{Contents}

List of Colour Plates 9

List of Black and White Plates 11

Acknowledgements 13

$\begin{array}{ll}\text { Introduction } & 19\end{array}$

Part 1 1700-89

Joseph Addison Marlborough at Blenheim 33

Anon. Admiral Benbow 33

Richard Leveridge The Roast Beef of Old England 34

James Thomson Rule, Britannia! 35

David Garrick Hearts of Oak 36

Thomas Arne Britain's Bulwarks 36

Voltaire (François-Marie Arouet) (tr. John Butt) from Candide $\quad 37$

Samuel Johnson The Vanity of Human Wishes (extract) 40

Anon. The British Grenadiers 41

John Scott The Drum 41

Part 2 1789-1815

William Blake A Song of Liberty 43

William Blake from America 44

François-René, Vicomte de Chateaubriand (tr. R. Baldick) from With the Emigrant Army 45

Anon. Jack Tar 55

Robert Southey The Battle of Blenheim 56

Samuel Taylor Coleridge from Fears in Solitude $\quad 57$

Anon. Drink Old England Dry 61

Anon. The Victory 61

William Wordsworth November $1806 \quad 62$

William Wordsworth Sonnet 1811 63

Robert Southey The March to Moscow 63

Anon. The Battle of Waterloo $\quad 65$

Anon. The Labouring Man 66 
Part 3 1816-1913

Karl von Clausewitz (tr. J. I. Greene) Moral Quantities in War

Alfred Lord Tennyson from Locksley Hall

Arthur Hugh Clough from Amours de Voyage 71

Anon. McCassery $\quad 72$

Sir Franklin Lushington Alma 74

Alfred Lord Tennyson The Charge of the Heavy Brigade at Balaclava

Alfred Lord Tennyson from Maud 77

Henry Lushington from Inkerman $\quad 79$

Count Leo Tolstoy (tr. Isabel F. Hapgood) from Sevastopol 80

John Bright From a Speech in the House of Commons 85

Robert H. Newell (Orpheus C. Kerr) Doings of the Mackerel Brigade, and Notes of the Latest Improvements in Artillery, etc.

Herman Melville Ball's Bluff-A Reverie

David Ross Locke (Petroleum V. Nasby) Shows Why He Should Not Be Drafted

Henry Timrod The Unknown Dead

Abraham Lincoln Address at the Dedication of the Gettysburg National Cemetery

Walt Whitman Beat! Beat! Drums!

Walt Whitman Reconciliation

Guy de Maupassant (tr. H. N. P. Sloman) The Capture of Walter Schnaffs

Arthur Rimbaud (tr. Robert Lowell) from EighteenSeventy

G. A. Henty from With Kitchener to Khartoum

Baroness von Suttner (tr. Andrea Hofer-Proudfoot) from Disarm! Disarm!

Stephen Crane from The Red Badge of Courage

G. W. Hunt We don't want to fight, from a music-hall song

W. E. Henley England, my England

Henry Newbolt Vitaï Lampada

A. E. Housman from A Shropshire Lad

Rudyard Kipling The Head of the District

Rudyard Kipling The 'Eathen

Rudyard Kipling Tommy

Rudyard Kipling Recessional

Rudyard Kipling Stellenbosch

Rudyard Kipling The Return 
Part 4 1913-24

Soldiers' Songs: We're Here Because, Raining, Mademoiselle from Armenteers, The Old Barbed Wire, Tipperary

Richard Aldington Trench Idyll

Richard Aldington from Death of a Hero

Guillaume Apollinaire (tr. O. Bernard) Calligram, 15 May 1915

Guillaume Apollinaire (tr. O. Bernard) Cornflower, 1917

Gabriele d'Annunzio (tr. John Ferguson) To a torpedoboat in the Adriatic

Isaac Babel (tr. W. Morison) The Death of Dolgushov

Laurence Binyon For the Fallen

Laurence Binyon From the Arras Road

Alexander Blok (tr. Jon Stallworthy and Peter France) Those Born in the Years of Stagnation

Alexander Blok (tr. Jon Stallworthy and Peter France) The Vulture

Robert Bridges Wake Up, England

Rupert Brooke 1914

Paul Claudel (tr. John Ferguson) The Virgin at Mid-day

John Drinkwater We Willed It Not

W. N. Ewer Five Souls

Stefan George (tr. Carol North Valhope and Ernst Morwitz)

To a Young Leader in the First World War

Wilfred Gibson In the Ambulance

Julian Grenfell Into Battle

Thomas Hardy Men Who March Away

Thomas Hardy In Time of 'The Breaking of Nations'

Thomas Hardy 'And There Was a Great Calm'

Jaroslav Hasek (tr. P. Selver) Schweik Joins the Army

W. N. Hodgson Before Action

A. E. Housman Epitaph on an Army of Mercenaries

David Jones from In Parenthesis

Ernst Jünger (tr. Basil Creighton) from The Storm of Steel

Rudyard Kipling For All We Have and Are

Rudyard Kipling Mine Sweepers

P. Wyndham Lewis The War Crowds, 1914: The Crowd, London, July 1914

E. A. Mackintosh Recruiting

John MacCrae In Flanders Fields

Claude McKay If We Must Die

Percy MacKaye Christmas: 1915

André Maurois (tr. Thurfrida Wake) from The Silences of Colonel Bramble 
Vladimir Mayakovsky (tr. Herbert Marshall) Our March 184

C. E. Montague from Rough Justice

H. H. Munro ('Saki') The Toys of Peace 187

Robert Nichols from Battle 191

Alfred Noyes The Search-Lights 194

Sean O'Casey from The Plough and the Stars 195

Wilfred Owen Preface 201

Wilfred Owen Strange Meeting 201

Wilfred Owen The Parable of the Old Man and the Young 202

Wilfred Owen Anthem for Doomed Youth 203

Wilfred Owen The Send-Off 203

Wilfred Owen At a Calvary Near the Ancre 204

Wilfred Owen Exposure 204

Wilfred Owen Dulce et Decorum Est 205

Wilfred Owen Futility 206

Wilfred Owen Greater Love 207

Wilfred Owen Insensibility 207

Charles Péguy (tr. Ann and Julian Green) Blessed Are 209

Herbert Read from The Scene of War, The Happy Warrior $\begin{array}{ll}\text { and Fear } & 210\end{array}$

Ernest Rhys Lost in France 211

Edgell Rickword Moonrise Over Battlefield 211

Lewis Anselm Ritchie ('Bartimeus') A Forty-Foot Setting 212

Isaac Rosenberg Break of Day in the Trenches 214

Siegfried Sassoon from Sherston's Progress 215

Siegfried Sassoon from Memoirs of a Fox-Hunting Man 216

Siegfried Sassoon Objections to the War 217

Siegfried Sassoon The General 218

Siegfried Sassoon The Dug-Out 218

Siegfried Sassoon 'Blighters' 218

Siegfried Sassoon 'They' 219

Siegfried Sassoon Everyone Sang 219

Osbert Sitwell The Next War 219

Charles Hamilton Sorley To Germany 221

Charles Hamilton Sorley Untitled 221

Cecil Spring-Rice I Vow to Thee, My Country 221

Sir J. C. Squire The Dilemma 222

Sir J. C. Squire The Trinity 222

G. A. Studdert-Kennedy Solomon in all his Glory 222

Edward Thomas A Private 223

Georg Trakl (tr. Michael Hamburger) Grodek 223

W. J. Turner The Sky-sent Death 224

R. E. Vernède England to the Sea 225

H. G. Wells from Mr Britling Sees It Through 227 
Arthur Graeme West God, How I Hate You

W. B. Yeats An Irish Airman Foresees His Death 232

W. B. Yeats The Second Coming 232

W. B. Yeats Meditations in Time of Civil War 233

Part 5 1925-38

T. S. Eliot Triumphal March

Jean Giraudoux (tr. Christopher Fry) from Tiger at the Gates

Hugh Macdiarmid Another Epitaph on an Army of Mercenaries

Dylan Thomas The Hand that Signed the Paper

Jef Last (tr. D. Hallett) Pajaro Negro (The Black Bird) 247

John Cornford from Full Moon at Tierz: Before the Storming of Huesca

John Cornford To Margot Heinemann

Alex MacDude Jarama Valley

Bertolt Brecht Song of the United Front

Roy Campbell from Flowering Rifle

Roy Campbell Dawn on the Sierra of Gredos

Part 6 1939-45

Soldiers' Songs of the Second World War

Anon. Hitler has only got one ball

Anon. I don't want to join the Army

Anon. Rule, Britannia!

Barry Amiel Death is a matter of mathematics

W. H. Auden Say This City

Walter Bauer (tr. Christopher Middleton) Showing Something to a Stranger

Wolfgang Borchert (tr. Elmer Suderman) Why Not?

Bertolt Brecht (tr. Christopher Middleton) When Men March Off to War

Norman Cameron Green, Green is El Aghir 262

Roy Campbell from Talking Bronco 262

Roy Campbell Imitation (and Endorsement) of the Famous Sonnet of Bocage which he wrote on Active Service Out East Winston Churchill Extracts from Wartime Speeches

Alex Comfort The Lemmings

Keith Douglas from Alamein to Zem Zem

272

Keith Douglas Syria

275

Keith Douglas Dead Men

Keith Douglas Simplify me when I'm Dead 277

Keith Douglas Vergissmeinicht

278

Keith Douglas Aristocrats 
Richard Eberhart The Fury of Aerial Bombardment 279

Paul Éluard (tr. Christopher Middleton) Enterrar y Callar 280

William Empson Ignorance of Death 280

David Gascoyne $A$ Wartime Dawn 281

Robert Graves The Persian Version 283

Joseph Heller from Catch-22 283

Hamish Henderson First Elegy: End of a Campaign 284

Richard Hillary from The Last Enemy 286

Randall Jarrell The Soldier Walks Under the Trees of the University

Randall Jarrell The Death of the Ball Turret Gunner

James Jones from The Thin Red Line

Sidney Keyes Advice for a Journey

Sidney Keyes War Poet

Alun Lewis Home Thoughts from Abroad 294

Alun Lewis The Mahratta Ghats 295

C. Day Lewis Where are the War Poets? 296

Eugenio Montale (tr. Robert Lowell) Hitlerian Spring 296

Anthony Powell from The Valley of Bones 297

F. T. Prince Soldiers Bathing 298

John Pudney For Johnny $\quad 300$

Henry Reed Lessons of the War 301

Alan Rook Dunkirk Pier 304

André Schwarz-Bart (tr. S. Becker) from The Last of the Just

305

Edith Sitwell Still Falls the Rain 309

Martyn Skinner Churchill 310

Richard Spender Before the First Parachute Descent 311

Stephen Spender Two Armies 311

Dylan Thomas A Refusal to Mourn the Death by Fire of a Child in London

James Thurber from The Secret Life of Walter Mitty 313

Laurens Van Der Post from A Bar of Shadows 314

Part 7 1946-71

Peter Appleton The Responsibility

Robert Bly Johnson's Cabinet Watched by Ants $\quad 320$

Algis Budrys The Price $\quad 320$

Grady and Hazel Cole The Tramp on the Street 323

Frantz Fanon (tr. Constance Farrington) Colonial War and Mental Disorders

Christopher Fry from The Dark is Light Enough

Che Guevara (tr. Victoria Ortiz) The Morale and Discipline of Revolutionary Fighters 
Jean Lartéguy (tr. Ian Fielding) Rue de la Bombe

Ed McCurdy Last Night I had the Strangest Dream

Sylvia Plath Daddy

Buffy Sainte-Marie Universal Soldier

Peter Seeger Where Have All the Flowers Gone?

Thich Nhat Hanh (tr. Vodinh) Condemnation

Notes on the Text

Notes on Illustrations

370

Index to Prose and Verse

373 


\section{List of Colour Plates}

\section{between pages 316 and 317}

I Paolo Uccello The Rout of San Romano, 1432 (c. 1450s)

II Pieter Brueghel (The Elder) The Massacre of the Innocents (1565-6)

III After Peter Paul Rubens The Horrors of War (mid-17th century)

IV Anonymous Charles I Dictating Despatches to Sir Edward Walker (date uncertain)

V Sir Joshua Reynolds Lord Heathfield (1787)

VI Jacques-Louis David Distribution of the Eagles (1810)

VII Carle Vernet Morning of the Battle of Austerlitz, 1805 (c. 1806-10)

VIII Jean-Antoine Gros Napoleon at Eylau, 1807 (c. 1807-8)

IX Francisco Goya The Charge of the Mamelukes (1814)

$\mathrm{X}$ Eugène Delacroix The Battle of Tailleburg (1837)

XI Edouard Manet The Fight between the Kearsage and the Alabama, 1864 (1864)

XII Paul Nash Totes Meer (Dead Sea) (1940-1)

XIII Henry Moore Pink and Green Sleepers (1941)

XIV John Piper St Mary le Port, Bristol, 1940 (1940)

XV Graham Sutherland The Crucifixion (1946) 


\section{List of Black and White Plates}

between pages 124 and 125

1 Anonymous The Siege of Orléans, 1428-9 (mid-15th century)

2 Anonymous Portuguese Musketeer (bronze) (date uncertain)

3 Jacques Callot Plundering a Farmhouse (1633)

4 Diego Velazquez The Surrender of Breda, 1625 (c. 1634-5)

5 D. Chodowiecki Frederick the Great Receiving the Surrender of the Army of Saxony, 1756 (1788)

6 William Blake War (1804)

7 James Gillray Caricature from The Life of William Cobbett (1809)

8 Francisco Goya Tan Poco (1810)

9 Honoré Daumier Refugees (bronze) (date unknown)

10 Phassily Vereschtschagin The Apotheosis of War (1871)

11 Oskar Kokoschka Knight-Errant (1915)

12 Umberto Boccioni The Cavalry Charge (1914)

13 Gino Severini The Armoured Train (1915)

14 Frank Reynolds Study of a Prussian Household Having its Morning Hate (1915)

15 Bruce Bairnsfather The Better 'ole (1915)

16 Franz Marc Strife (1915)

17 Mark Gertler Merry-go-round (1916)

18 Fernand Léger Soldiers Playing Cards (1917)

19 Muirhead Bone Night Shift working on a Big Gun (1917)

20 George Grosz Fit for Active Service (1916-17)

21 Mikhail Larionov Russian Soldiers (1908)

22 C. R. W. Nevinson La Mitrailleuse (1915)

23 C. R. W. Nevinson After a Push (undated)

24 John Nash Oppy Wood 1917: Evening (1917)

25 Paul Nash The Menin Road (1918)

26 William Roberts A Group of British Generals (undated)

27 Wyndham Lewis A Battery Shelled (1919)

28 William McMillan Tired Soldier (bronze) (undated) 
29 Stanley Spencer Map Reading (1927-32)

30 Stanley Spencer The Resurrection (1927-32)

31 Käthe Kollwitz Die Freiwilligen (The Volunteers) (1923)

32 Georges Rouault Homo Homini Lupus (date uncertain)

33 Pablo Picasso Guernica (1937)

34 John Armstrong Pro Patria (1938)

35 Ossip Zadkine Commemorative Monument of the Destruction of Rotterdam (sculpture) (1953-4)

36 V. K. Dmitrievski Crossing the Volga in 1942 (date uncertain)

37 Graham Sutherland Devastation 1941: City, Twisted Girders (1941)

38 Pablo Picasso Still Life with Candlestick (1944)

39 Jack Levine Welcome Home (1947)

40 Andrew Wyeth The Patriot (1964)

41 John Armstrong The Battle of Nothing (1949)

42 Henry Moore Atom Piece (sculpture) (1964-5)

43 Juan Genoves Uno dos Siete, Siete (1968) 


\section{Acknowledgements}

The author and publishers wish to thank the following, who have kindly given permission for the use of copyright material: George Allen \& Unwin Ltd for 'Home Thoughts from Abroad' and 'The Mahratta Ghats' from Ha Ha Among the Trumpets by Alun Lewis, and for 'The Dilemma' and 'The Trinity' from The Survival of the Fittest by J. C. Squire; B. C. Amiel, 'Death is a matter of Mathematics' from Poets of the 1939-45 War edited by R. N. Currey; Peter Appleton, 'The Responsibility' from Rhyme and Reasan; Mrs. George Bambridge, and Macmillan \& Co. Ltd for The Head of the District by Rudyard Kipling; Mrs George Bambridge, Methuen \& Co. and The Macmillan Company of Canada for 'The 'Eathen' from L'Envoi, 'Stellenbosch', 'The Return' and 'Recessional' from The Five Nations, 'For All We Have and Are' from The Years Between, 'Tommy' from Barrack Room Ballads, and 'The MineSweepers' from Definitive Verse by Rudyard Kipling; William Blackwood \& Sons Ltd for 'The Search-Lights' by Dr Alfred Noyes from Collected Poems, and for 'A Forty-Foot Setting' by Lewis Anselm Ritchie in 'Bartimeus Omnibus' from Naval Occasions; The Bodley Head for 'Dawn of the Sierra of Gredos' and 'Imitation (and Endorsement) of the Famous Sonnet of Bocage which he wrote on Active Service Out East' from The Collected Poems of Roy Campbell, vol. 2, and for The Silence of Colonel Bramble by André Maurois, trans. Thurfrida Wake; Calder \& Boyars Ltd for 'The Crowd, London, July 1914' from Blasting and Bombardiering by P. Wyndham Lewis; Jonathan Cape Ltd for the extract from Catch 22 by Joseph Heller, for 'Full Moon at Tierz: Before the Storming of Huesca' and 'To Margot Heinemann' by John Cornford from John Cornford: A Memoir, edited by Pat Sloan, and for 'Naming of Parts', 'Judging Distances' and 'Unarmed Combat' by Henry Reed from 'Lessons of the War' in A Map of Verona; Jonathan Cape Ltd and Hogarth Press for 'Where are the War Poets?' by C. Day Lewis from Collected. Poems 1954; Jonathan Cape Ltd and the George Trakl Estate for 'Grodek' by George Trakl, trans. Michael Hamburger, from Selected Poems; Cassell \& 
Co. Ltd for extracts from The War Speeches, vols. i, ii and iii, by Winston S. Churchill; Chatto and Windus Ltd for 'The Fury of Aerial Bombardment' from Collected Poems of Richard Eberhart, for 'Ignorance of Death' by William Empson from Collected Poems, and for the extract from The Storm of Steel by Ernst Jünger, trans. Basil Creighton; Mrs Rose Elton and Chatto \& Windus Ltd for the extract from Rough Justice by C. E. Montague; the Estate of the late Harold Owen and Chatto \& Windus Ltd for ten poems from The Collected Poems of Wilfred Owen and the short Preface; Clarendon Press, Oxford, for 'Wake Up England' by Robert Bridges from Poems of the Great War; Rosica Colin Ltd for 'Trench Idyll' by Richard Aldington from Collected Poems, and for the extract from Death of a Hero by Richard Aldington (C) Catherine Guillaume; Collins Publishers for the extract from The Thin Red Line by James Jones; Curtis Brown Ltd for the extract from Flowering Rifle by Roy Campbell; André Deutsch Ltd and Rapp \& Whiting for 'Johnson's Cabinet Watched by Ants' from The Light Around the Body by Robert Bly (C) Robert Bly 1967; Dixie Music Publishing Company, U.S.A., for 'The Tramp on the Street' by Grady and Hazel Cole from Songs for Our Times; Enitharmon Press, London, for 'Moonrise over Battlefield' by Edgell Rickword from Collected Poems; Essex Music Group for 'Last Night I Had the Strangest Dream' by Ed McCurdy; W. N. Ewer, 'Five Souls' from Poetry of the First World War edited by M. Hussey; Eyre-Methuen Ltd for 'When Men March Off to War' by Bertolt Brecht from Ohne Hass und Fahne, trans. Christopher Middleton; Eyre \& Spottiswoode (Publishers) Ltd for 'Those Born in Years of Stagnation' and 'The Vulture' from The Twelve and Other Poems by Alexander Blok, trans. J. Stallworthy and P. France; Faber \& Faber Ltd for 'Refugee Blues' ('Say this city has ten million souls') from Collected Shorter Poems 1927-1957 by W. H. Auden, for the extract from 'Monologue' from Talking Bronco by Roy Campbell, for 'Aristocrats', 'Vergissmeinicht', 'Simplify me when I'm dead', 'Syria I' and 'Dead Men' by Keith Douglas from Collected Poems and the extract from Alamein to Zern Zem by Keith Douglas, for 'Triumphal March' by T. S. Eliot from Collected Poems 1909-1962, for 'The Soldier Walks Under the Trees of the University' and 'The Death of the Ball Turret Gunner' by Randall Jarrell from The Complete Poems, for the extract from In Parenthesis by David Jones, for Eugenio Montale's 'Hitlerian Spring' and Arthur Rimbaud's 'EighteenSeventy: i A Poster of Our Dazzling Victory at Saarbrucken, iii To the French of the Second Empire, and vii The Sleeper in the Valley' from Imitations by Robert Lowell, for 'The Happy Warrior' and 'Fear' from Collected Poems by Herbert Read, for 
extracts from Memoirs of a Fox-Hunting Man and Sherston's Progress by Siegfried Sasson, for 'Two Armies' by Stephen Spender from Collected Poems 1928-1953, and for 'Daddy' from Ariel by Sylvia Plath (C) Ted Hughes 1965; Fellowship of Reconciliation for 'Why Not?' by Wolfgang Borchert, trans. Elmer Suderman; Fortune Press for 'Soldier Bathing' by F. T. Prince from Poems of Today; Éditions Gallimard for 'Enterrar y Caller' from Le Lit, la Table by Paul Eluard, trans. Christopher Middleton (c) Éditions Gallimard 1968, and for 'The Virgin at Midday' by Paul Claudel from Euvre Poétique (C) Éditions Gallimard 1957, trans. John Ferguson; David Gascoyne for 'A Wartime Dawn' from Poems 1937-42; Michael Gibson for 'In the Ambulance' from Collected Poems by Wilfred Gibson; Robert Graves for 'The Persian Version' from Collected Poems 1965 by Robert Graves; Mrs Nicolete Gray and the Society of Authors on behalf of the Laurence Binyon Estate for 'From the Arras Road' and 'For the Fallen' by Laurence Binyon from Laurence Binyon Anthology; Hamish Hamilton Ltd for the extract from The Memoirs of Chateaubriand, trans. Robert Baldick (C) 1961, and for 'The Secret Life of Walter Mitty' from Vintage Thurber by James Thurber, (C) 1963; Trustees of the Estate of Thomas Hardy for 'Drummer Hodge', 'Men Who March Away', 'In Time of the Breaking of Nations' and 'There Was a Great Calm' from The Collected Poems of Thomas Hardy; Harmony Music Ltd for 'Where Have all the Flowers Gone' by Pete Seeger; Jaroslav Hasek and Paul Selver for extracts from The Good Soldier Schweik by Jaroslav Hasek, trans. Paul Selver; William Heinemann Ltd for the extract from The Valley of Bones by Anthony Powell; Hamish Henderson for 'First Elegy: End of a Campaign' from Elegies for the Dead in Cyrenaica; David Higham Associates Ltd for 'For Johnny' by John Pudney from Collected Poems, published by Putnam, for 'Still Falls the Rain' from The Canticle of the Rose by Edith Sitwell, and for 'The Next War' by Osbert Sitwell from Selected Poems, published by J. M. Dent \& Sons; Michael Hillary for the extract from The Last Enemy by Richard Hillary; Hodder \& Stoughton for Solomon in All His Glory by G. A. Studdert Kennedy, copyright; Hogarth Press for the extract from $A$ Bar of Shadow by Laurens Van Der Post, and for 'Green, Green is El Aghir' from Collected Poems of Norman Cameron 1905-1953; Hutchinson Publishing Group Ltd for 'Rue de la Bombe' from The Centurions by Jean Lartéguy, trans. Ian Fielding; Robert Lantz-Candida Donadio Literary Agency Inc. for 'The Price' by Algis Budrys from Science Fiction (C) 1962 by A. J. Budrys; Hugh MacDiarmid, 'Another Epitaph on an Army of Mercenaries' from Second Hymn to Lenin and Other Poems; MacGibbon \& Kee Ltd for the extract from The 
Wretched of the Earth by Frantz Fanon, trans. Constance Farrington; Olga Marx and Ernst Morwitz (trans.) The Works of Stefan George University of North Carolina Studies in the Germanic Languages and Literatures, No. 2. Chapel Hill: University of North Carolina Press 1949, p. 298 (Reprint, New York: AMS Press, 1966); Methuen \& Co. Ltd for 'The Death of Dolgushov' from The Collected Stories of Isaac Babel, trans. W. Morison, and for the extract from Tiger at the Gates by Jean Giraudoux, trans. Christopher Fry; Monthly Review Press for 'The Morale and Discipline of Revolutionary Fighters' from Reminiscences of the Cuban Revolutionary War by Che Guevara, trans. Victoria Ortiz (C) 1968 Monthly Review Press; Mrs Eileen O'Casey for the extract from 'The Plough and the Stars' by Sean O'Casey in Collected Plays I; Oxford University Press for the extract from The Dark is Light Enough by Christopher Fry; Penguin Books Ltd for 'Cornflower', 'Calligram (15 May 1915)' by Guillaume Apollinaire from Selected Poems, trans. Oliver Bernard (C) by Oliver Bernard 1965, for the extract from chap. 3 of Candide by Voltaire, trans. John Butt, copyright Estate of John Butt 1947, and for 'The Capture of Walter Schnaffs', trans. H. N. P. Sloman from Boule de Suif and Other Stories by Guy de Maupassant, copyright H. N. P. Sloman 1946; A. D. Peters \& Co. for 'Jarama Valley' by Alex MacDude from The Last Great Cause, edited by Stanley Weintraub; Routledge \& Kegan Paul Ltd for the extract from The Spanish Tragedy by Jef Last, trans. David Hallett, for 'The Lemmings' from Letters from an Outpost by Alex Comfort, for 'Advice for a Journey' and 'War Poet' from Collected Poems of Sidney Keyes, and for 'Dunkirk Pier' from Soldiers this Solitude by Alan Rook; Rowholt Verlag, Hamburg, and Dr Walter Bauer, for 'Showing Something to a Stranger' from Das blaue Oktavheft by Walter Bauer, trans. Christopher Middleton; G. T. Sassoon for 'The General', 'They', 'Blighters', 'Everyone Sang' and 'The Dugout' by Siegfried Sassoon from Collected Poems; Secker \& Warburg Ltd for the extract from The Last of the Just by André Schwartz-Bart, trans. S. Becker; Sidgwick \& Jackson Ltd for We Willed it Not by John Drinkwater, and for 'Before the First Parachute Descent' by Richard Spender from Collected.Poems; Martyn Skinner for 'Churchill' from Letters to Malaya by Martyn Skinner; the Society of Authors as the literary representative of the Estate of A. E. Housman and Jonathan Cape Ltd publishers of A. E. Housman's Collected Poems for 'Epitaph on an Army of Mercenaries' and 'On the Idle Hill of Summer' from $A$ Shropshire Lad by A. E. Housman; Southern Music Ltd for 'Universal Soldier' by Buffy Sainte-Marie; Trustees for the copyrights of the late Dylan Thomas and J. M. Dent \& Sons Ltd for 'A Refusal to Mourn' and 'The Hand that Signed 
the Paper' from Collected Poems of Dylan Thomas; Twayne Publishers Inc. for 'If We Must Die' from Selected Poems of Claude McKay, copyright 1953 by Bookman Associates; Unicorn Press for 'Condemnation' by Thich Nhat Hanh from The Cry of Vietnam, trans. Vodinh (C) 1968 by Thich Nhat Hanh; Milton Waldman and Chatto \& Windus for 'The Assault' from 'Battle' in Ardours and Endurances by Robert Nichols; George Weidenfeld \& Nicolson Ltd for 'Our March' by Vladimir Mayakovsky from The Bedbug and Selected Poetry; the Estate of H. G. Wells for the extract from Mr. Britling Sees it Through by H. G. Wells; M. B. Yeats, Macmillan \& Co. Ltd and The Macmillan Company of Canada Ltd for 'Meditation in time of Civil War', 'An Irish Airman Foresees His Death' and 'The Second Coming' from The Collected Poems of W. B. Yeats.

The publishers have made every effort to trace the copyrightholders, but if they have inadvertently overlooked any, they will be pleased to make the necessary arrangement at the first opportunity. 